\title{
The herbicide treatment of oil flax on leached chernozem of the Western Ciscaucasia
}

\author{
Vyacheslav M. Lucomets, Alexander S. Bushnev", and Gennady I. Orekhov \\ V.S. Pustovoit All-Russian Research Institute of Oil Crops, 17 Filatova street, Krasnodar, 350038, \\ Russia
}

\begin{abstract}
The work is aimed at the development of application methods of graminicides and anti-dicotyledonous herbicides on oil flax in the area of unstable moistening of the south of Russia. The application of preparations against dicotyledonous weeds Tifi, Sekator Turbo or Magnum, followed by the treatment of sowings with Miura graminicide, contributed to obtaining an increase in yield of $0.14,0.12$, and $0.11 \mathrm{t} / \mathrm{ha}$, respectively, in comparison to the untreated sowings. We observed an increase in crop yield by 0.09 $0.12 \mathrm{t} / \mathrm{ha}$ with the application of anti-dicotyledonous herbicide Cleo and graminicide Miura, regardless of their application method. The tank mixtures Tifi + Miura and Magnum + Miura had a phytotoxic effect on oil flax, which, in comparison to the control, led to a decrease in yield by 0.04 and $0.09 \mathrm{t} / \mathrm{ha}$ and in oil content of seeds by 1.1 and $0.8 \%$, respectively.
\end{abstract}

\section{Introduction}

The high demand in the global market of agricultural products contributes to the steady growth of production of oil flax - an export-oriented crop. General reliability and the ability to effectively use winter deposits of moisture allow it to be cultivated in various soil and climatic areas of the country and to obtain good yields even under the conditions of insufficient moistening. As a result, there was a noticeable increase in crop acreage under oil flax in the Russian Federation, which over the period of 2014-2019 increased 1.6 times, and over the period of 2000-2019 - 37 times (from 22 to 814 thousand hectares). However, the flax yield varies widely. For example, in 2018, in the Central Federal District of Russia it ranged from 0.10 to $1.51 \mathrm{t} /$ ha by region: in the Volga region - from 0.10 to $1.28 \mathrm{t} / \mathrm{ha}$, in the South region - from 0.38 to $0.71 \mathrm{t} / \mathrm{ha}$, in the North Caucasus - from 0.52 to $1.00 \mathrm{t} / \mathrm{ha}$, in the Siberian region - from 0.69 to $1.10 \mathrm{t} / \mathrm{ha}$. One of the reasons for this is the inefficient control of weeds, the potential losses from which can exceed $25 \%$ [1], which puts the ensuring of sowings purity from weeds in the first place in the technology of crop cultivation.

Several Russian and foreign researchers dealt with the problems of herbicides application in flax cultivation technologies [2-6]. It was noted that in the conditions of western Canada, the application of herbicides provided a decrease in the weed biomass by $50 \mathrm{~kg} / \mathrm{ha}$, contributing to an increase in the flax yield to $0.6 \mathrm{t} / \mathrm{ha}$ [7]. Due to the wide variety of weeds that populate flax fields, it becomes necessary to use the tank mixtures of herbicides with

\footnotetext{
* Corresponding author: vniimk-agro@mail.ru
} 
various components that provide control of a wide range of suppressed weeds. However, it is necessary to ensure the absence of phytotoxicity of both individual components and the tank mixture in general. Research on flax tolerance to chemical plant protection products carried out by M.E. Kurtenbach, E.N. Johnson, R.H. Gulden, and C.J. Willenborg showed that herbicides with the active ingredients of flutiacet-methyl, pyroxasulfone and topramezone and their tank mixtures did not have a significant effect on the flax yield, and the combination of flutiacet-methyl and topramezone with MCPA and bromoxynil is not recommended due to their phytotoxic effect on the crop [8]. When assessing the effect of various herbicide treatments on flax yield, the research of H. Karimmojeni, A.G. Pirbaloti, P. Kudsk, V. Kanani, and A. Ghafori showed that bromoxynil in a tank mixture with MCPA provided the efficient weed control but caused damage to the yield and led to a greater decrease in yield [9].

Thus, the issues of herbicide treatments, which are characterized by efficient control of a wide range of weeds in oil flax sowings, provided that there is no phytotoxic effect on the crop, are scientifically relevant, and the results of the research will find extensive practical application.

Several preparations are registered in the "State catalog of pesticides and agrochemicals permitted for use on the territory of the Russian Federation" for the control of monocotyledonous weeds on the oil flax crop. One of them is Miura, EC (a.i. chizalofop-Pethyl) - 0.8-1.2 1/ha, which can be used against perennial (Agropyron repens L.) and annual grass weeds. For the suppression of annual and some perennial broad-leaved weeds in the crop sowings, such preparations as Tifi, WDG (a.i. thifensulfuron-methyl) $-0.025 \mathrm{~kg} / \mathrm{ha}$, Magnum, WDG (a.i. metsulfuron-methyl) - 0.008-0.01 kg/ha, Herbitox, SC (a.i. dimethylamine + potassium + sodium salts) $-0.8-1.0 \mathrm{~kg} / \mathrm{ha}$, Cleo, WDG (a.i. clopyralid) $0.12 \mathrm{~kg} / \mathrm{ha}$, Sekator Turbo, OD (a.i. amidosulfuron + iodosulfuron-methyl-sodium + mefenpyr-diethyl) $-0.05-0.1 \mathrm{~kg} / \mathrm{ha}$ and others were registered. The use of tank mixtures of herbicides is practiced to suppress a wide range of weeds, however, tank mixtures are not always characterized by the absence of phytotoxicity on the crop, often reducing its yield and the quality of obtained seeds $[10,11]$. Therefore, in case of phytotoxicity manifestation, one of the methods to maintain productivity without losing the herbicides effectiveness is the separate application of preparations.

The aim of the work is to identify the most efficient herbicide treatments on oil flax in the south of Russia.

\section{Materials and methods}

We carried out the research at V.S. Pustovoit All-Russian Research Institute of Oil Crops (Krasnodar) in 2018-2020 on leached chernozem of the Western Ciscaucasia. We used two schemes on sowings of oil flax variety FLIZ at the phase of true leaves development: 1) alternate spraying of sowings with anti-dicotyledonous herbicides and graminicides (separate application); 2) spraying of sowings with a tank mixture of herbicides. The experiment scheme included the following herbicide treatments:

1. Control I, without treatment;

2. Control II, manual weeding;

3. Tank mixture Tifi, WDG $(0.025 \mathrm{~kg} / \mathrm{ha})+$ Miura, EC (1.2 1/ha);

4. Separate application of Tifi, WDG $(0.025 \mathrm{~kg} / \mathrm{ha})$ and Miura, EC (1.2 1/ha);

5. Tank mixture Magnum, WDG $(0.01 \mathrm{~kg} / \mathrm{ha})+$ Miura, EC (1.2 1/ha);

6. Separate application of Magnum, WDG $(0.01 \mathrm{~kg} / \mathrm{ha})$ and Miura, EC (1.2 1/ha);

7. Tank mixture Herbitox, SC (1.0 kg/ha) + Miura, EC (1.2 1/ha);

8. Separate application of Herbitox, SC $(1.0 \mathrm{~kg} / \mathrm{ha})$ and Miura, EC (1.2 1/ha);

9. Tank mixture Cleo, WDG $(0.12 \mathrm{~kg} / \mathrm{ha})+$ Miura, EC (1.2 1/ha); 
10. Separate application of Cleo, WDG $(0.12 \mathrm{~kg} / \mathrm{ha})$ and Miura, EC (1.2 1/ha);

11. Tank mixture Miura, EC (1.2 l/ha) + Sekator Turbo, OD (0.1 l/ha);

12. Separate application of Miura, EC (1.2 1/ha) and Sekator Turbo, OD (0.1 1/ha);

We used the cultivation technology recommended for the region [12]. The size of the experimental plot was $12.0 \mathrm{~m}^{2}$, the number of replications was four, the plots placement was randomized. We sprayed the flax sowings with herbicides at the onset of phase of true leaves development according to the application regulations. We determined the oil content in oil flax seeds by nuclear magnetic resonance in accordance with State Standard R 8.620-2006. The yield was harvested by direct combining and normalized to $100 \%$ of purity and $12 \%$ of moisture content of the seeds.

\section{Results and discussion}

In the past few years, the region has experienced weather conditions unusual for spring. As a rule, spring has become continuous, its beginning is characterized by low average daily temperature and a lack of precipitation, which leads to an uneven emergence of seedlings of cultivated plants and weeds. In 2018 and 2019, the growth season was favorable for the development of oil flax both in terms of the initial deposits of moisture in soil, and in the amount and distribution of precipitation in the subsequent period. 2020 was characterized by a deficit of moisture necessary for the development of crop: in the pre-sowing period, 193.4 $\mathrm{mm}$ of precipitation fell, which is 1.68 times lower than the average long-term values -325.0 $\mathrm{mm}$, and from April to June, $75 \mathrm{~mm}$ of precipitation fell, or $43.6 \%$ of the average long-term norm. Arid conditions hampered the development of oil flax and, at the same time, contributed to the low infestation of fields with annual weeds: in the period from April to July, their number ranged from 0 to $5 \mathrm{pcs} / \mathrm{m}^{2}$. The excess water in July $(126.0 \mathrm{~mm})$ contributed to the secondary flowering of oil flax, complicating the harvesting process (Table $1)$.

Table 1. The precipitation distribution during the research period, $\mathrm{mm}$

\begin{tabular}{|c|c|c|c|c|c|c|}
\hline \multirow{2}{*}{ Year } & \multirow{2}{*}{$\begin{array}{l}\text { The amount of } \\
\text { precipitation for } \\
\text { October-March }\end{array}$} & \multicolumn{4}{|c|}{ Month } & \multirow{2}{*}{$\begin{array}{l}\text { The amount of } \\
\text { precipitation for } \\
\text { April-July }\end{array}$} \\
\hline & & IV & V & VI & VII & \\
\hline $\begin{array}{l}\text { Long-term annual } \\
\text { average }\end{array}$ & 325.0 & 48.0 & 57.0 & 67.0 & 60.0 & 232.0 \\
\hline 2018 & 472.9 & 17.6 & 86.0 & 11.0 & 119.2 & 233.8 \\
\hline 2019 & 352.5 & 45.5 & 120.0 & 41.5 & 73.5 & 280.5 \\
\hline 2020 & 193.4 & 4.4 & 44.8 & 25.8 & 126.0 & 201.0 \\
\hline
\end{tabular}

The average daily temperature during the growth season of oil flax in the years of research differed from the average long-term values, exceeding them in the summer months up to 5 ${ }^{\circ} \mathrm{C}$ (Table 2). The growth and development of oil flax plants took place against an increased temperature background, which led to a decrease in the level of crop productivity. 
Table 2. The average daily temperature during the growth season of oil flax for the research period, oC

\begin{tabular}{|l|c|c|c|c|c|}
\hline \multirow{2}{*}{ Year } & \multicolumn{4}{|c|}{ Month } & \multicolumn{1}{c|}{$\begin{array}{c}\text { The average for } \\
\text { April-July }\end{array}$} \\
\cline { 2 - 6 } & IV & V & VI & VII & \\
\hline \multirow{2}{*}{$\begin{array}{l}\text { Long-term annual } \\
\text { average }\end{array}$} & 10.9 & 16.8 & 20.4 & 23.2 & 17.8 \\
\hline 2018 & 13.5 & 19.0 & 23.5 & 26.3 & 20.6 \\
\hline 2019 & 11.0 & 21.8 & 25.4 & 23.4 & 20.4 \\
\hline 2020 & 10.8 & 17.2 & 23.6 & 26.4 & 19.5 \\
\hline
\end{tabular}

In the process of research, we revealed that, on average, over three years, the separate application of herbicides contributed to the development of higher yields than the use of herbicides in a tank mixture: Tifi and Miura - by $0.18 \mathrm{t} / \mathrm{ha}$, Magnum and Miura - by 0.20 $\mathrm{t} / \mathrm{ha}$ (Table 3 ). We also recorded an increase of the yield level in comparison with the control I (without treatment) by 0.14 and $0.11 \mathrm{t} / \mathrm{ha}$.

Table 3. The productivity of oil flax under different methods of herbicide application

\begin{tabular}{|c|c|c|c|c|c|c|}
\hline \multicolumn{3}{|c|}{ Variant } & \multicolumn{4}{|c|}{ Productivity, $\mathrm{t} / \mathrm{ha}$} \\
\hline No & herbicide & $\begin{array}{l}\text { application } \\
\text { method }\end{array}$ & 2018 & 2019 & 2020 & $\begin{array}{l}\text { average for } \\
\text { three years }\end{array}$ \\
\hline 1 & Control I (without treatment) & - & 1.24 & 1.28 & 1.24 & 1.25 \\
\hline 2 & Control II (manual weeding) & - & 1.45 & 1.42 & 1.24 & 1.37 \\
\hline 3 & \multirow{2}{*}{$\begin{array}{l}\text { Tifi, WDG }(0.025 \mathrm{~kg} / \mathrm{ha}) \text {, } \\
\text { Miura, EC (1.2 1/ha) }\end{array}$} & tank mixture & 1.20 & 1.19 & 1.25 & 1.21 \\
\hline 4 & & separate & 1.59 & 1.38 & 1.21 & 1.39 \\
\hline 5 & \multirow{2}{*}{$\begin{array}{l}\text { Magnum, WDG }(0.01 \mathrm{~kg} / \mathrm{ha}) \text {, } \\
\text { Miura, EC (1.2 1/ha) }\end{array}$} & tank mixture & 1.26 & 1.09 & 1.12 & 1.16 \\
\hline 6 & & separate & 1.44 & 1.35 & 1.28 & 1.36 \\
\hline 7 & \multirow{2}{*}{$\begin{array}{l}\text { Herbitox, SC (1.0 kg/ha), } \\
\text { Miura, EC (1.2 1/ha) }\end{array}$} & tank mixture & 1.26 & 1.17 & 1.26 & 1.23 \\
\hline 8 & & separate & 1.33 & 1.34 & 1.16 & 1.28 \\
\hline 9 & \multirow{2}{*}{$\begin{array}{l}\text { Cleo, WDG }(0.12 \mathrm{~kg} / \mathrm{ha}) \text {, } \\
\text { Miura, EC (1.2 1/ha) }\end{array}$} & tank mixture & 1.36 & 1.49 & 1.25 & 1.37 \\
\hline 10 & & separate & 1.29 & 1.47 & 1.26 & 1.34 \\
\hline 11 & \multirow{2}{*}{$\begin{array}{l}\text { Sekator Turbo, OD }(0.1 \text { 1/ha }) \text {, } \\
\text { Miura, EC }(1.2 \text { 1/ha) }\end{array}$} & tank mixture & 1.28 & 1.12 & 1.31 & 1.24 \\
\hline 12 & & separate & 1.34 & 1.40 & 1.38 & 1.37 \\
\hline \multicolumn{3}{|c|}{$\mathrm{HMD}_{05}$} & 0.14 & 0.13 & 0.16 & 0.16 \\
\hline
\end{tabular}

In case of application of Sekator Turbo and Miura, we noted a significant advantage of the separate application only in 2019, and in case of application of Cleo and Miura, the method of application did not significantly affect the flax productivity. 
We noted the highest oil content of seeds, $45.7 \%$, in the control variants (Table 4), as well as in separate application of Magnum and Miura, Cleo and Miura.

Table 4. The oil content of oil flax seeds under different methods of herbicide application

\begin{tabular}{|c|c|c|c|c|c|c|}
\hline \multicolumn{3}{|c|}{ Variant } & \multicolumn{4}{|c|}{ Oil content of seeds, $\%$} \\
\hline $\begin{array}{l}\mathrm{N} \\
\mathrm{o}\end{array}$ & herbicide & $\begin{array}{l}\text { application } \\
\text { method }\end{array}$ & 2018 & 2019 & 2020 & $\begin{array}{l}\text { average for } \\
\text { three years }\end{array}$ \\
\hline 1 & $\begin{array}{l}\text { Control I } \\
\text { (without treatment) }\end{array}$ & - & 46.3 & 45.0 & 45.7 & 45.7 \\
\hline 2 & $\begin{array}{l}\text { Control II } \\
\text { (manual weeding) }\end{array}$ & - & 46.0 & 45.4 & 45.6 & 45.7 \\
\hline 3 & \multirow{2}{*}{$\begin{array}{l}\text { Tifi, WDG }(0.025 \mathrm{~kg} / \mathrm{ha}) \text {, } \\
\text { Miura, EC }(1.21 / \mathrm{ha})\end{array}$} & tank mixture & 44.9 & 43.4 & 45.4 & 44.6 \\
\hline 4 & & separate & 45.7 & 44.7 & 45.6 & 45.3 \\
\hline 5 & \multirow{2}{*}{$\begin{array}{l}\text { Magnum, WDG }(0.01 \\
\mathrm{kg} / \mathrm{ha}), \\
\text { Miura, EC (1.2 1/ha) }\end{array}$} & tank mixture & 45.7 & 43.7 & 45.3 & 44.9 \\
\hline 6 & & separate & 45.9 & 45.4 & 45.7 & 45.7 \\
\hline 7 & \multirow{2}{*}{$\begin{array}{l}\text { Herbitox, SC (1.0 1/ha), } \\
\text { Miura, EC (1.2 l/ha) }\end{array}$} & $\operatorname{tank}$ mixture & 45.8 & 44.3 & 45.5 & 45.2 \\
\hline 8 & & separate & 46.3 & 44.8 & 45.5 & 45.5 \\
\hline 9 & \multirow{2}{*}{$\begin{array}{l}\text { Cleo, WDG }(0.12 \mathrm{~kg} / \mathrm{ha}) \text {, } \\
\text { Miura, EC }(1.2 \mathrm{l} / \mathrm{ha})\end{array}$} & tank mixture & 46.0 & 45.0 & 45.5 & 45.5 \\
\hline 10 & & separate & 46.1 & 44.9 & 46.0 & 45.7 \\
\hline 11 & \multirow{2}{*}{$\begin{array}{l}\text { Sekator Turbo, OD (0.1 } \\
\text { 1/ha), Miura, EC (1.2 1/ha) }\end{array}$} & tank mixture & 45.7 & 44.0 & 45.7 & 45.1 \\
\hline 12 & & separate & 45.8 & 44.6 & 45.9 & 45.4 \\
\hline \multicolumn{3}{|c|}{$\mathrm{HMD}_{05}$} & 0.57 & 0.66 & 0.50 & 0.56 \\
\hline
\end{tabular}

The application of other herbicides negatively affected the quality of flax seeds, reducing their oil content regardless of the application method. We found that in all cases the oil content of seeds was $0.2-0.8 \%$ higher with the separate application of herbicides than with the usage of tank mixtures. We recorded the greatest decrease in the oil content of seeds in case of application of the tank mixture Magnum + Miura $-0.8 \%$.

\section{Conclusions}

In the conditions of the area of unstable moistening of the south of Russia, the separate application at the phase of true leaves development of one of the anti-dicotyledonous herbicides Tifi, WDG (a.i. thifensulfuron-methyl) - $0.025 \mathrm{~kg} / \mathrm{ha}$, Sekator Turbo, OD (a.i. amidosulfuron + iodosulfuron-methyl-sodium + mefenpyr-diethyl) - 0.1 1/ha, or Magnum, WDG (a.i. metsulfuron-methyl) - $0.01 \mathrm{~kg} / \mathrm{ha}$, and graminicide Miura, EC (a.i. chizalofop-Pethyl) $-1.2 \mathrm{l} /$ ha provide highly effective protection of oil flax from weeds, which contributes to obtaining high yields and yield increase of $0.14,0.12$, and $0.11 \mathrm{t} / \mathrm{ha}$, respectively, in comparison with the untreated sowings. In case of spraying sowings with the antidicotyledonous herbicide Cleo, WDG (a.i. clopyralid) $-0.12 \mathrm{~kg} / \mathrm{ha}$ and graminicide Miura, EC $-1.21 /$ ha, we observed high productivity indicators regardless of their application method - in a tank mixture or separately. Tank mixtures of anti-dicotyledonous herbicides Tifi, WDG - $0.025 \mathrm{~kg} / \mathrm{ha}$ and Magnum, WDG $-0.01 \mathrm{~kg} / \mathrm{ha}$ with graminicide Miura, EC $-1.2 \mathrm{l} / \mathrm{ha}$ contributed to a decrease in yield by 0.04 and $0.09 \mathrm{t} / \mathrm{ha}$ and in oil content of seeds by 1.1 and $0.8 \%$, respectively, compared to the untreated sowings, these preparations are better to use separately. 


\section{References}

1. L. M. Zakharova, Plant protection and quarantine 3, 23 (2016)

2. J. Mańkowski, K. Pudełko, J. Kołodziej, T. Karaś, Industrial Crops and Products 70, 185 (2015)

3. E. I. Lupova, E. A. Vysotskaya, D. V. Vinogradov, 6th International Conference on Agricultural products Processing and Farming, (APaF 2019), 422 (2020)

4. S. Andruszczak, U. Gawlik-Dziki, P. Kraska, E. Kwiecińska-Poppe, K. Różyło, E. Pałys, Plant, Soil and Environment, 61, 247 (2015)

5. K. Harrington, S. Gregory, New Zealand Plant Protection 62, 368 (2009)

6. K. Pudełko, J. Mańkowski, J. Kołodziej, Journal of Natural Fibers 12, 72 (2015)

7. M. E. Kurtenbach, E. N. Johnson, R. H. Gulden, S. Duguid, M. Dyck, C. J. Willenborg, Agronomy Journal, 111(4), 1904 (2019)

8. M. E. Kurtenbach, E. N. Johnson, R. H. Gulden, C. J. Willenborg, Weed Technology 33 (3), 509 (2019)

9. H. Karimmojeni, A. Pirbaloti, P. Kudsk, V. Kanani, A. Ghafori, Agronomy Journal 105 (3), 821 (2013)

10. A. S. Bushnev, G. I. Orekhov, S. P. Podlesny, Yu. V. Mamyrko, Oil Crops 4, 133 (2019)

11. A. S. Bushnev, G. I. Orekhov, S. P. Podlesny, Yu. V. Mamyrko, T. N. Luchkina, A. B. Khatit, Oil Crops 2, 76 (2020)

12. Adaptive technologies of oil crops cultivation (VNIIMK, 2017) 